\title{
Aerodynamic Investigation of Incidence Angle Effects in a Large Scale Transonic Turbine Cascade
}

Ashlie B. McVetta

Glenn Research Center, Cleveland, Ohio

Paul W. Giel

Vantage Partners, LLC, Brook Park, Ohio

Gerard E. Welch

Glenn Research Center, Cleveland, Ohio 


\section{NASA STI Program . . . in Profile}

Since its founding, NASA has been dedicated to the advancement of aeronautics and space science. The NASA Scientific and Technical Information (STI) program plays a key part in helping NASA maintain this important role.

The NASA STI Program operates under the auspices of the Agency Chief Information Officer. It collects, organizes, provides for archiving, and disseminates NASA's STI. The NASA STI program provides access to the NASA Aeronautics and Space Database and its public interface, the NASA Technical Reports Server, thus providing one of the largest collections of aeronautical and space science STI in the world. Results are published in both non-NASA channels and by NASA in the NASA STI Report Series, which includes the following report types:

- TECHNICAL PUBLICATION. Reports of completed research or a major significant phase of research that present the results of NASA programs and include extensive data or theoretical analysis. Includes compilations of significant scientific and technical data and information deemed to be of continuing reference value. NASA counterpart of peer-reviewed formal professional papers but has less stringent limitations on manuscript length and extent of graphic presentations.

- TECHNICAL MEMORANDUM. Scientific and technical findings that are preliminary or of specialized interest, e.g., quick release reports, working papers, and bibliographies that contain minimal annotation. Does not contain extensive analysis.

- CONTRACTOR REPORT. Scientific and technical findings by NASA-sponsored contractors and grantees.
- CONFERENCE PUBLICATION. Collected papers from scientific and technical conferences, symposia, seminars, or other meetings sponsored or cosponsored by NASA.

- SPECIAL PUBLICATION. Scientific, technical, or historical information from NASA programs, projects, and missions, often concerned with subjects having substantial public interest.

- TECHNICAL TRANSLATION. Englishlanguage translations of foreign scientific and technical material pertinent to NASA's mission.

Specialized services also include creating custom thesauri, building customized databases, organizing and publishing research results.

For more information about the NASA STI program, see the following:

- Access the NASA STI program home page at http://www.sti.nasa.gov

- E-mail your question to help@sti.nasa.gov

- Fax your question to the NASA STI Information Desk at 443-757-5803

- Phone the NASA STI Information Desk at 443-757-5802

- Write to: STI Information Desk NASA Center for AeroSpace Information 7115 Standard Drive Hanover, MD 21076-1320 


\section{Aerodynamic Investigation of Incidence Angle Effects in a Large Scale Transonic Turbine Cascade}

Ashlie B. McVetta

Glenn Research Center, Cleveland, Ohio

Paul W. Giel

Vantage Partners, LLC, Brook Park, Ohio

Gerard E. Welch

Glenn Research Center, Cleveland, Ohio

Prepared for the

48th Joint Propulsion Conference and Exhibit

cosponsored by AIAA, ASME, SAE, and ASEE

Atlanta, Georgia, July 29-August 1, 2012

National Aeronautics and

Space Administration

Glenn Research Center

Cleveland, Ohio 44135 


\section{Acknowledgments}

This work is supported under the NASA Fundamental Aeronautics Program, Subsonic Rotary Wing Project. The authors would like to acknowledge the assistance of Doug Thurman (ARL) with acquiring hotwire measurements.

Trade names and trademarks are used in this report for identification only. Their usage does not constitute an official endorsement, either expressed or implied, by the National Aeronautics and Space Administration.

This work was sponsored by the Fundamental Aeronautics Program at the NASA Glenn Research Center.

Level of Review: This material has been technically reviewed by technical management.

Available from

NASA Center for Aerospace Information 7115 Standard Drive

Hanover, MD 21076-1320
National Technical Information Service 5301 Shawnee Road Alexandria, VA 22312

Available electronically at http://www.sti.nasa.gov 


\title{
Aerodynamic Investigation of Incidence Angle Effects in a Large Scale Transonic Turbine Cascade
}

\author{
Ashlie B. McVetta \\ National Aeronautics and Space Administration \\ Glenn Research Center \\ Cleveland, Ohio 44135 \\ Paul W. Giel \\ Vantage Partners, LLC \\ Brook Park, Ohio 44142 \\ Gerard E. Welch \\ National Aeronautics and Space Administration \\ Glenn Research Center \\ Cleveland, Ohio 44135
}

\begin{abstract}
Aerodynamic measurements showing the effects of large incidence angle variations on an HPT turbine blade set are presented. Measurements were made in NASA's Transonic Turbine Blade Cascade Facility which has been used in previous studies to acquire detailed aerodynamic and heat transfer measurements for CFD code validation. The current study supports the development of variable-speed power turbine (VSPT) speed-change technology for the NASA Large Civil Tilt Rotor (LCTR) vehicle. In order to maintain acceptable main rotor propulsive efficiency, the VSPT operates over a nearly 50 percent speed range from takeoff to altitude cruise. This results in $50^{\circ}$ or more variations in VSPT blade incidence angles. The cascade facility has the ability to operate over a wide range of Reynolds numbers and Mach numbers, but had to be modified in order to accommodate the negative incidence angle variation required by the LCTR VSPT operation. Using existing blade geometry with previously acquired aerodynamic data, the tunnel was re-baselined and the new incidence angle range was exercised. Midspan exit total pressure and flow angle measurements were obtained at seven inlet flow angles. For each inlet angle, data were obtained at five flow conditions with inlet Reynolds numbers varying from $6.83 \times 10^{5}$ to $0.85 \times 10^{5}$ and two isentropic exit Mach numbers of 0.74 and 0.34 . The midspan flowfield measurements were acquired using a three-hole pneumatic probe located in a survey plane 8.6 percent axial chord downstream of the blade trailing edge plane and covering three blade passages. Blade and endwall static pressure distributions were also acquired for each flow condition.
\end{abstract}

\section{Nomenclature}

$C p_{s} \quad$ static pressure coefficient, $C p_{s}=\left(P-\bar{P}_{2}\right) /\left(P_{t, 1}-\bar{P}_{2}\right)$

$C p_{t} \quad$ total pressure coefficient, $C p_{t}=\left(P_{t, 1}-P_{t}\right) /\left(P_{t, 1}-\bar{P}_{2}\right)$

$C_{x} \quad$ blade axial chord [in]

$i \quad$ incidence angle $[\mathrm{deg}], i=\beta_{1}-\beta_{1, \text { des }}$

M Mach number

$P R \quad$ Pressure Ratio, $P R=P_{t, 1} / \bar{P}_{2}$ 


$\begin{array}{ll}\text { PS } & \text { pressure Surface } \\ \bar{P} & \text { area-averaged static-pressure } \\ \bar{P} & \text { area-averaged total-pressure } \\ R e & \text { Reynolds number, } R e=\rho \mathrm{U}_{1} \mathrm{C}_{\mathrm{x}} / \mu \\ s & \text { blade pitch [in] } \\ \mathrm{SS} & \text { suction surface } \\ U & \text { total velocity } \\ x & \text { chordwise (axial) direction } \\ y & \text { tangential coordinate }[\text { in }] \\ Z w & \text { Zweifel coefficient, } Z w=\frac{2 s}{C_{x}} \cos ^{2} \bar{\beta}_{2}\left(\tan \beta_{1}-\tan \bar{\beta}_{2}\right) \\ \beta & \text { Relative flow angle }[\text { deg] } \\ \bar{\beta}_{2} & \text { Angle of mass-averaged velocity components } \\ \delta & \text { Boundary layer thickness }[\text { in] } \\ \mu & \text { Dynamic viscosity } \\ \rho & \text { Density } \\ \omega & \text { Loss coefficient, }\left(P_{t, 1}-\bar{P}_{t, 2}\right) /\left(P_{t, 1}-\bar{P}_{2}\right)\end{array}$

\section{Subscripts}

des Design value

$1 \quad$ Cascade inlet value

$2 \quad$ Cascade exit value

$i \quad$ Isentropic value

\section{Introduction}

A conceptual Large Civil Tilt Rotor (LCTR) (Ref. 1) vehicle and mission have been developed as a part of NASA's on-going work to improve the capacity of airspace systems (Refs. 2 and 3). In order to minimize mission fuel burn, the main rotor speeds are varied from 100 percent at takeoff to 54 percent at cruise as required to optimize prop efficiency at cruise. The speed variation can be accomplished through several means, including a variable gear-ratio (two-speed) transmission (Ref. 4), which adds complexity associated with gear shifting and weight. Another approach is to use a variable speed power turbine (VSPT) (Refs. 5 and 6). The VSPT will operate at a relatively fixed corrected flow and, therefore the incidence flow angle to the power turbine rotor blades will vary by $50^{\circ}$ or more over the range of VSPT shaft speeds. The current VSPT research effort at NASA Glenn Research Center (Ref. 7) addresses the aerodynamic challenges of a VSPT for NASA's LCTR. As a part of this effort, an experimental database, required for the improvement and validation of turbine design methods and computational tools, is being established (Ref. 7). This will enable the design and optimization of incidence-tolerant blade rows for future VSPT applications. 
Little detailed experimental data are available in the open literature to support the assessment of the impact of extreme negative incidence on blade-row performance. Two previous studies (Refs. 8 and 9) examined incidence loss levels of turbine rotor blades with blunt and sharp leading edges, and each study also varied the pressure ratio. The authors found that loss is more sensitive to positive incidence angles, and that loss levels were higher for the sharp leading edge profile. The ranges of incidence studied in both tests $\left(25^{\circ}\right.$ and $\left.30^{\circ}\right)$ were at a considerably narrower range than spanned by VSPT operation.

In addition to the large incidence variation, the cruise altitude ( $28 \mathrm{k}-\mathrm{ft})$ of the LCTR requires that the VSPT operate with Reynolds numbers associated with transitional flows. The impact of Reynolds number lapse on turbine efficiency, and the allowable speed-range of operation with acceptable efficiency, is a key consideration in design and analysis. Similarly, few relevant data sets exist in the open literature related to the aerodynamic impact of Reynolds number lapse on turbine efficiency and operability. An experimental data set is needed in order to have increased confidence in predictions by CFD and empirical models for the combined aerodynamic impact of large incidence and Reynolds number.

The NASA Transonic Turbine Blade Cascade facility is well-suited for obtaining detailed aerodynamic data over a wide range of Reynolds numbers, Mach numbers, and incidence angles. An "incidence-tolerant" (IT) blade (Ref. 10) design is currently being tested in the facility. The IT blade required that the cascade be rotated to incidence angles beyond its original operational range due to mechanical limits; therefore, several features of the facility were redesigned to extend the negative incidence angle range to be compatible with VSPT requirements.

To document and verify the aerodynamic results of the new modifications, a blade used in a previous aerodynamic test was chosen for this study. The test blade is a scaled rotor tip section of the GE Energy Efficient Engine (EEE) design (Ref. 11) that has an axial chord of 5.119 in. (130.0 mm), a blade pitch of 5.119 in. $(130.0 \mathrm{~mm})$, a span of 6.000 in. $(152.4 \mathrm{~mm})$, and a design-intent inlet flow angle of $\beta_{1}=+29.7^{\circ}$. This blade geometry was considered to be a good test case because direct comparisons could be made between data obtained before and after the tunnel modifications. The EEE data will also provide a good first data set for CFD validation over a large incidence range and transitional Reynolds numbers (Ref. 12).

Exit total pressures, flow angles, blade loading, exit static pressures, and endwall pressures were acquired over a wide range of Reynolds numbers, including Reynolds numbers low enough to admit transitional flows as determined from previous studies in the facility (Ref. 13). The test matrix (see Table 1) included the design inlet Reynolds number of 683,000 and points at $1 / 2,1 / 4$, and $1 / 8$ of this value. The design pressure ratio for this blade is 1.441, giving an exit isentropic Mach number of $M_{2, i}=0.74$.

TABLE 1.-NOMINAL FLOW CONDITIONS

[See Appendix for actual conditions.]

\begin{tabular}{|lcc|}
\hline \multicolumn{1}{|c|}{ Inlet Reynolds number } & Pressure ratio & $\begin{array}{c}\text { Exit isentropic } \\
\text { Mach number }\end{array}$ \\
\hline 683,000 (Design) & 1.44 & 0.74 \\
341,500 (1/2 Design) & 1.44 & 0.74 \\
170,700 (1/4 Design) & 1.44 & 0.74 \\
170,700 (1/4 Design) & 1.08 & 0.34 \\
85,000 (1/8 Design) & 1.08 & 0.34 \\
\hline
\end{tabular}

TABLE 2.-INLET FLOW ANGLES
\begin{tabular}{|cc|}
\hline Inlet angle, & Incidence angle, \\
$\beta_{1}$ & $\beta_{1-} \beta_{\text {design }}$ \\
\hline $58.8^{\circ}$ & $29.1^{\circ}$ \\
$48.8^{\circ}$ & $19.1^{\circ}$ \\
$38.8^{\circ}$ & $9.1^{\circ}$ \\
$33.8^{\circ}$ & $4.1^{\circ}$ \\
$18.3^{\circ}$ & $-11.4^{\circ}$ \\
$-2.4^{\circ}$ & $-32.1^{\circ}$ \\
$-16.8^{\circ}$ & $-46.5^{\circ}$ \\
\hline
\end{tabular}


The 1/8 Reynolds number case would have fallen outside of the operating envelope at the design pressure ratio, so it was run at a reduced pressure ratio of $1.081\left(M_{2, i}=0.34\right)$. The impact of reducing the exit Mach number to establish the lowest Reynolds number was assessed, in terms of loading and loss, during the course of the study. The 1/4 Reynolds number cases were run at both pressure ratios for comparison.

It is recognized that losses would scale more appropriately with exit Reynolds number, but measurements of the current study were based on the inlet Reynolds number for consistency with previous measurements on this same blade that focused on tip surface heat transfer and aerodynamics. The ratio of $R e_{C x, 2} / R e_{C x, 1}$ varied with inlet flow angle and $P R$. All values are listed in the Appendix. As listed in Table 2, seven incidence angles were tested ranging from $+29.1^{\circ}$ to $-46.5^{\circ}$. The $+29.1^{\circ}$ and $+9.1^{\circ}$ incidence cases were repeated to re-baseline the tunnel modifications. Along with the tunnel re-baselining, the data from this current study will also provide a valuable and challenging experimental data set for CFD validation and will provide insight on the expected trends of Reynolds number and incidence angle variation.

\section{Facility Description and Modification Details}

\section{Facility Description}

The Transonic Turbine Blade Cascade has been used for a wide range of turbine blade tests, including the aerodynamic tests that produced detailed flow field data for CFD code validation (Ref. 14). The cascade, shown in Figure 1, was described in detail by Verhoff et al. (Ref. 15) and early modifications that were made to the inlet to improve the inlet flow uniformity were described by Giel et al. (Ref. 16). A wide range of engine relevant inlet Reynolds numbers and exit Mach numbers can be achieved as seen in the facility operating envelope shown in Figure 2. Clean, dry, ambient temperature air is supplied to the cascade and the inlet pressure can be independently varied up to 14.7 psia under current facility restrictions as seen by the red dashed line. Under normal operation, a maximum inlet pressure of 23 psia can be achieved. The air is exhausted through a center-wide altitude exhaust system in which the pressure is maintained at 2 psia. The facility can run continuously at mass flows up to $58 \mathrm{lbm} / \mathrm{s}$. The cascade test section nominally comprises eleven blade passages. The blades are attached to a rotating disc to allow for incidence angle adjustment. Upper and lower flow boards are used to direct the air from an upstream contraction section to the airfoils. The upper flow board is pinned to the rotating disc while the lower board moves independently. The boards are adjusted to be horizontal while their hinged leading edges are maintained in the same plane normal to the inlet flow.

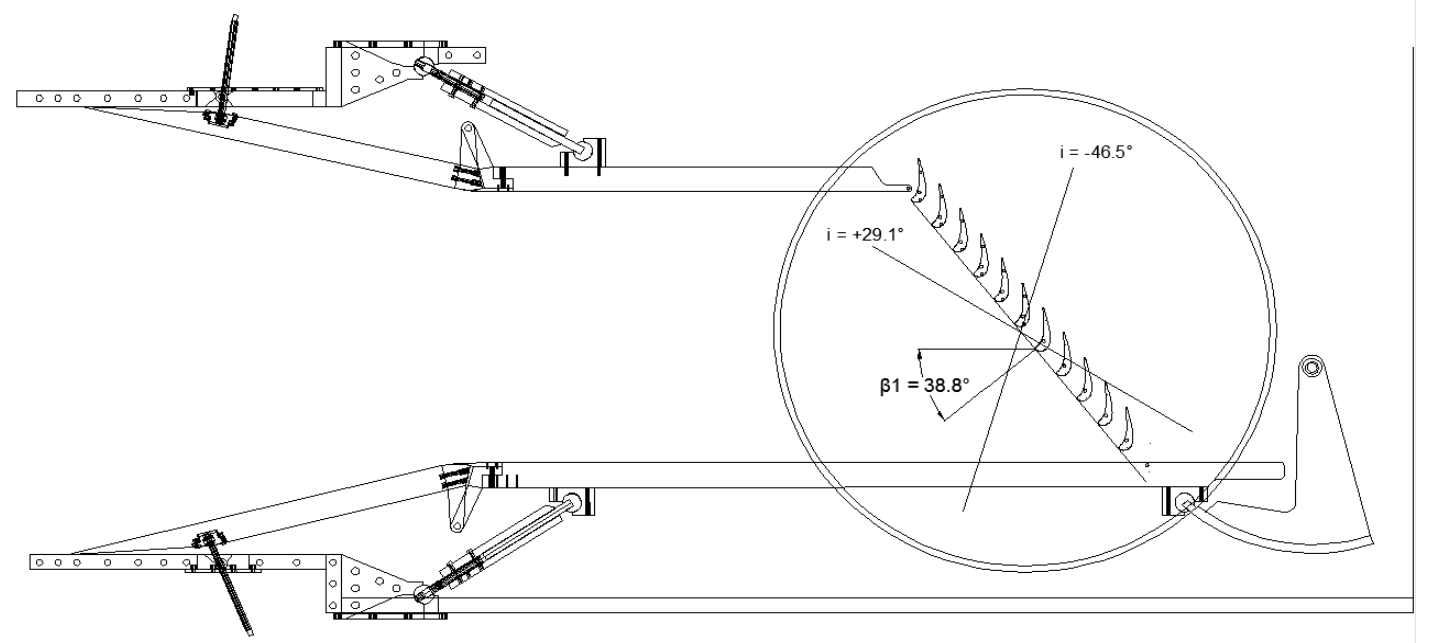

Figure 1.-Cascade Layout With EEE Blades at $\beta_{1}=38.8^{\circ}\left(i=+9.1^{\circ}\right)$. 


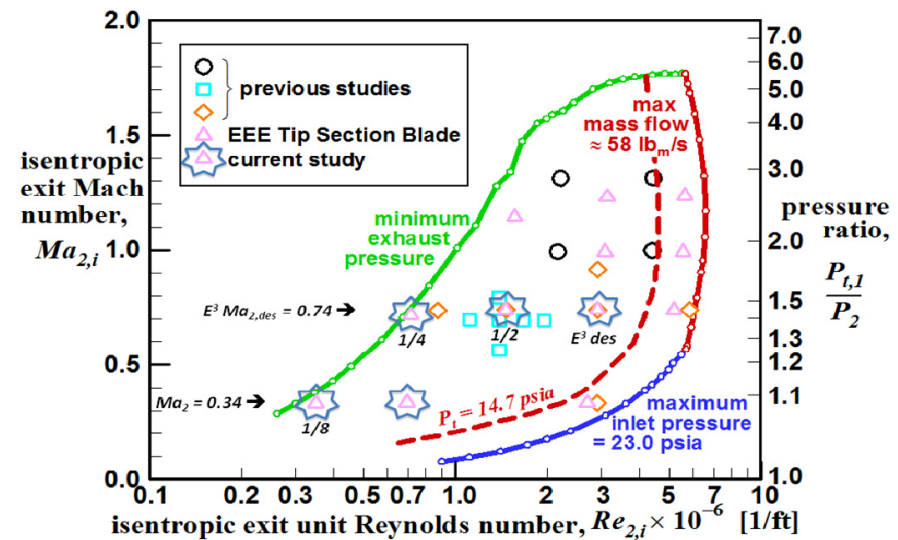

Figure 2.-Operating Envelope of NASA Transonic Turbine Cascade.

\section{Facility Modifications}

Under the original facility configuration, the rotating disc (Fig. 1) allowed a $45^{\circ}$ variation in inlet flow angles ranging from $+33.8^{\circ}$ to $+78.6^{\circ}$ as measured from axial. This range was suitable when testing typical high pressure turbine blade designs but testing VSPT blade designs requires lower inlet flow angles for more negative incidence. The previous facility configuration, shown in Figure 3, was restricted to smaller negative incidence angles due to limitations on the hinge mechanism of the upper extension board, which can be seen in more detail in Figure 1. To solve this issue the upper board was moved to the minimum inlet angle limit, disconnected from the disc, and pinned to the fixed sidewall, making it independent of the test section. This allows the cascade to move independently of the two inlet boards. Since the upper board is fixed in place as the cascade is rotated in the negative incidence direction, the gap between the first blade and the end of the upper board increases, requiring discrete extension boards for each inlet angle to be tested. For this study, three extension boards were used to test the $-11.4^{\circ}$, $-32.1^{\circ}$, and $-46.5^{\circ} \mathrm{EEE}$ incidence angles.

Other factors which impacted the aerodynamic quality of the cascade limited the cascade's ability to rotate to negative angles. Under the original facility configuration, shown in Figure 3, the exhaust duct extended over three-quarters of the top of the facility, leaving the upper-right corner blocked off. Figure 4 shows the cascade section with a possible candidate IT blade design at a large negative incidence angle. In the configuration shown, it is evident that the airflow would be directed towards the upper-right corner of the cascade which, in the old configuration, is substantially blocked. As shown in Figure 4, a new exhaust duct was built that extends across the entire top section of the facility. The test section also had three large supporting blocks in the flow path around the disc, shown in Figure 3, which were needed to support the sidewalls under pressure or vacuum conditions. Two of the smaller blocks caused interference with the lower board when rotating to the larger inlet angles. The large block, located downstream of the blade cascade, had the potential to cause detrimental blockage when lower exit flow angle blades are installed. All three blocks were removed and replaced with seven $0.812 \mathrm{in}$. diameter bars located around the circumference of the disc. The bars are easily removable to allow the disc to rotate without interfering with any of the flow boards.

The facility modifications allow for a range of inlet angles $-17^{\circ} \leq \beta_{1} \leq+78.6^{\circ}$. The facility is shown in Figure 1 with the cascade at the EEE baseline inlet flow angle and the most positive $\left(+29.1^{\circ}\right)$ and negative incidence $\left(-46.5^{\circ}\right)$ angles that were tested. 


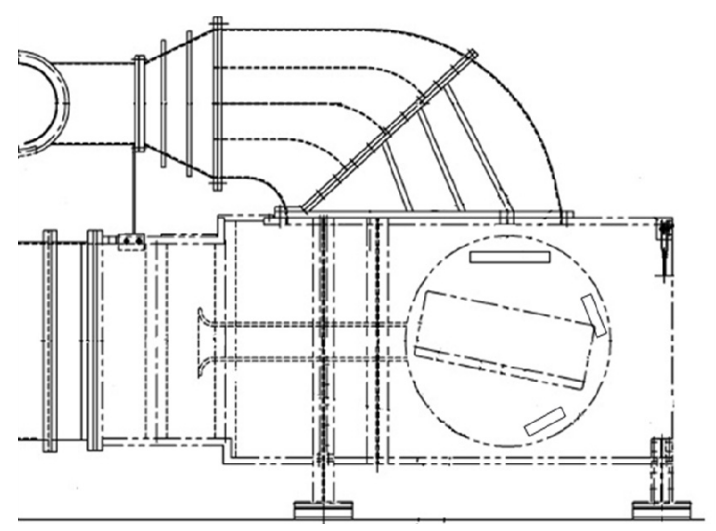

Figure 3.-Facility Before Modifications.

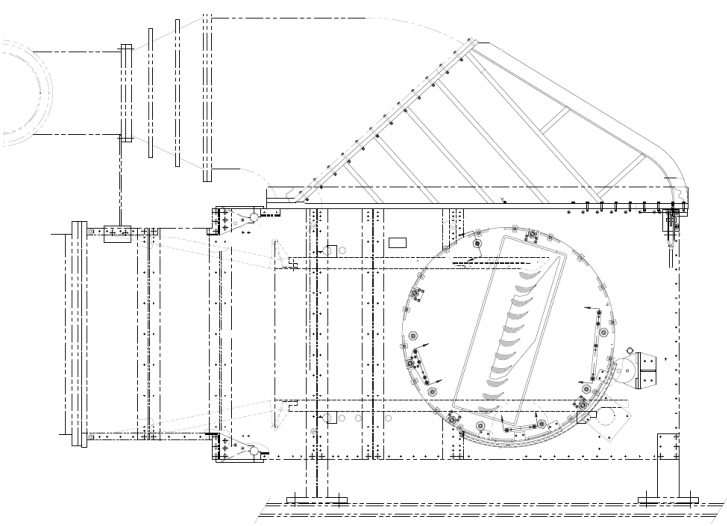

Figure 4.-Facility After Modifications.

\section{Measurements}

Downstream total-pressure and exit flow angle data were obtained using a three-hole pneumatic probe shown in Figure 5. The probe is a $45^{\circ}$ forward-facing pyramid probe with the measurement ports located on the shaft centerline. Probe measurement methods and calibration procedures similar to those described in Giel et al. (Ref. 14) were used. The time response on a comparable probe was measured to be to be $0.42 \mathrm{sec}$ including all tubing and pressure transducers. A $3 \mathrm{sec}$ delay between the time the probe reaches the desired survey location and when data are recorded is imposed to ensure a 99 percent time recovery. The probe pitch angle coefficient was monitored to ensure that it remained within the angular calibration range. If needed, the probe survey was stopped and the probe was approximately nulled before resuming. The probe was installed in a survey plane 8.6 percent axial chords downstream of the blades that covered three blade passages (Station 2 in Fig. 6). The probe can traverse in a spanwise direction but for this study only midspan survey data were obtained. The survey consisted of 104 points over the three passages. Consistent with the uncertainty reported by Giel et al., (Ref. 14) the overall estimated uncertainty in flow angle was $\pm 1.5^{\circ}$ and the overall estimated uncertainty in total-pressure coefficient was \pm 1.7 percent.

Three blades were instrumented with pressure static taps to measure blade loading. The main measurement blade, blade 5, was instrumented with taps at 5.5, 25, 50, 75, and 97.5 percent of span. To verify periodicity redundant 50,75 , and 97.5 percent, taps were placed on the suction side of blade 4 and blade 6 was instrumented with 50 and 97.5 percent span taps on its pressure side. Because of the midspan focus of the current study, only data from the 25,50 , and 75 percent span taps will be presented. The test section endwall is fully instrumented with 87 pressure static taps located in each blade passage and both upstream and downstream of the blade row. The endwall tap locations can be seen on Figure 6 . Twelve exit static taps located approximately three and half axial chords downstream of the blades spanning over nearly nine pitches are used to set the exit flow condition. Inlet total pressure and temperature were measured with two inlet combination Kiel/total-temperature probes located on either side of the primary measurement passages approximately one axial chord upstream of the blades. Up to six inlet static pressure taps, depending on inlet flow angle, were used to determine the inlet static pressure at that same axial location (see Fig. 6). As seen in Figure 2, the facility has a long section upstream of the cascade that generates relatively thick endwall inlet boundary layers. The inlet boundary-layer thickness is estimated by Reynolds number scaling of detailed inlet boundary-layer measurements acquired during a previous study (Ref. 14). For the current study, the estimated boundary-layer thickness for each test condition can be found in the Table 3 of the Appendix. 
Inlet turbulence intensity measurements were made with a constant temperature single-wire hotwire probe that was installed in Station 0, located approximately one axial chord upstream of the blades (see Fig. 6). The data were acquired at a rate of $92 \mathrm{kHz}$ for $7 \mathrm{sec}$. The uncertainties in the measurements were calculated (Ref. 17) to be less than 4 percent for the mean velocities and 5 percent for the fluctuations. All flow measurements of the current study were made without an inlet turbulence generating grid. The turbulence intensities, calculated as the normalized root-mean square of the velocity fluctuations, ranged from 0.25 to 0.40 percent.

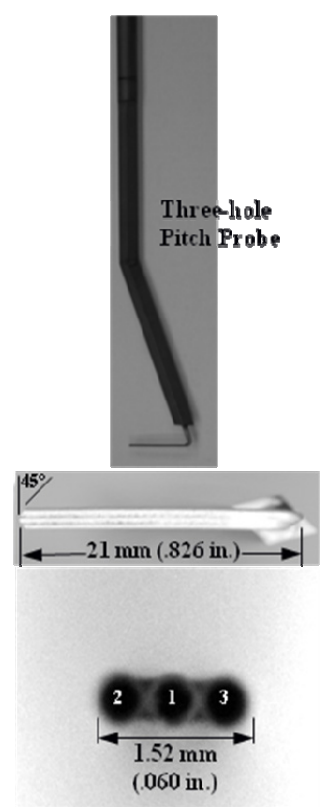

Figure 5.-Three-Hole Probe Details.

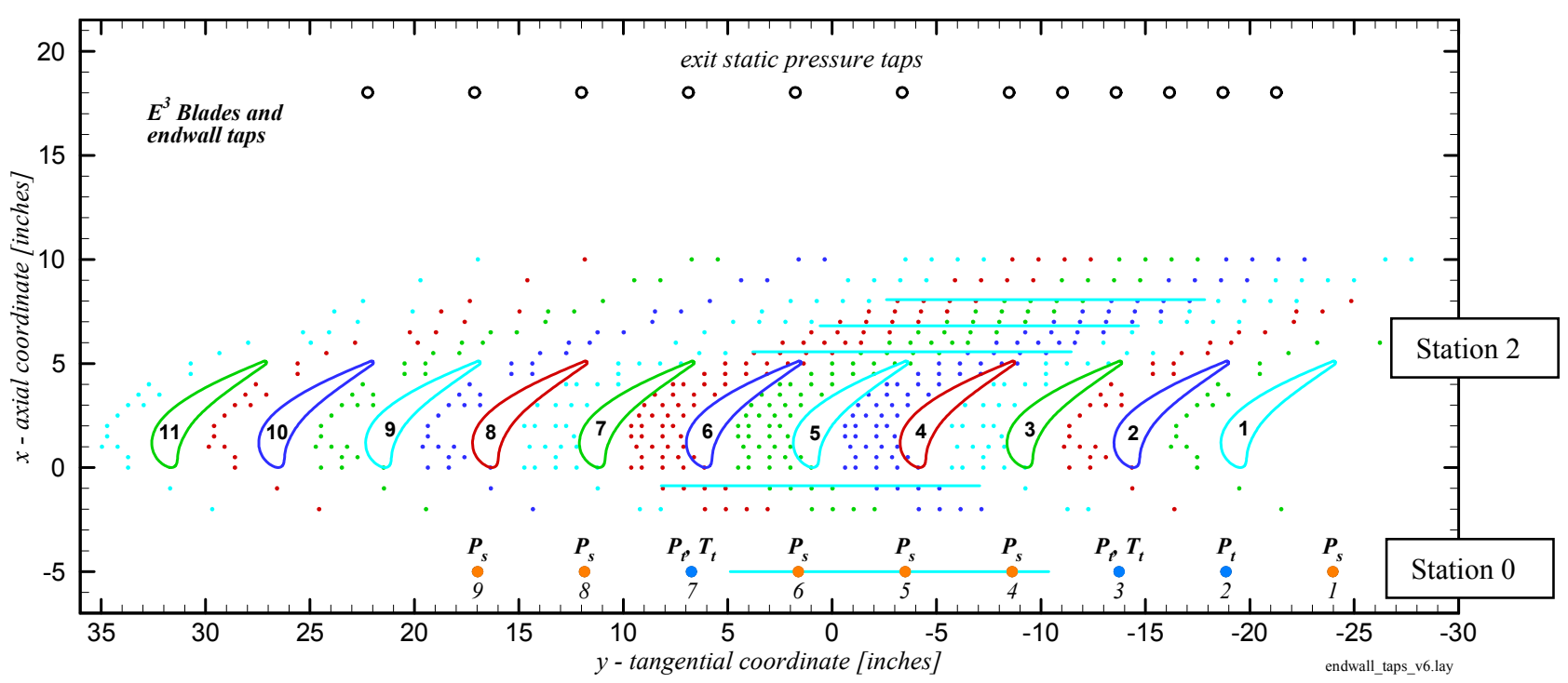

Figure 6. $-\mathrm{E}^{3}$ Endwall Static Taps and Survey Locations. 


\section{Results}

\section{Re-baseline Measurement Results}

The cascade was re-baselined after the tunnel modifications in order to document any aerodynamic effects caused by the new exhaust section and the support blocks. Midspan total pressures, exit flow angles, endwall static pressure, blade loading, and exit static pressures were previously acquired with the original tunnel configuration at incidence angles of $+4.1^{\circ},+9.1^{\circ},+19.1^{\circ}$, and $+29.1^{\circ}$. The $+9.1^{\circ}$ and $+29.1^{\circ}$ incidence points were repeated with the new configuration. A comparison of the exit static pressure data in Figures 7 and 8 show that the exit static pressure uniformity has improved with the new exhaust configuration. As previously mentioned, the average of the twelve exit static pressures (Fig. 6) is used to set the exit Mach number. This improved uniformity will result in improved periodicity and a more accurate setting of exit Mach number (pressure ratio).

Although the exit pressures improved for positive incidence, nonuniform exit static pressures are measured as the cascade is rotated to negative incidence angles as seen in Figures 9 and 10. Illustrated in Figure 4, as the cascade is rotated beyond the axial position to a negative incidence, the blade-pack and tunnel back wall establish a converging exhaust section. The converging section (nozzle) accelerates the flow field as it exhausts, establishing a negative pressure gradient. This gradient is impressed on the blade-pack exit as a pitchwise static pressure nonuniformity (see, for example, Fig. 9). The data of Figures 7 to 10 were obtained at the highest Reynolds number, but all other conditions showed very similar results.

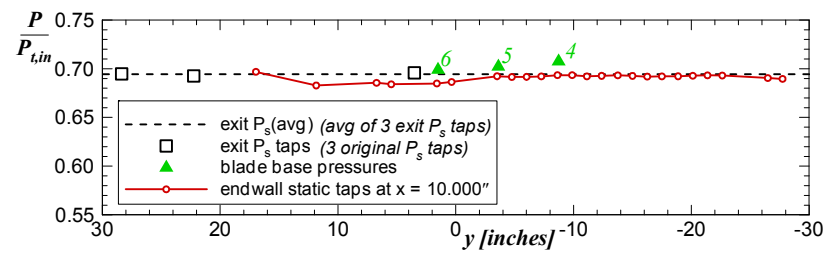

(a)

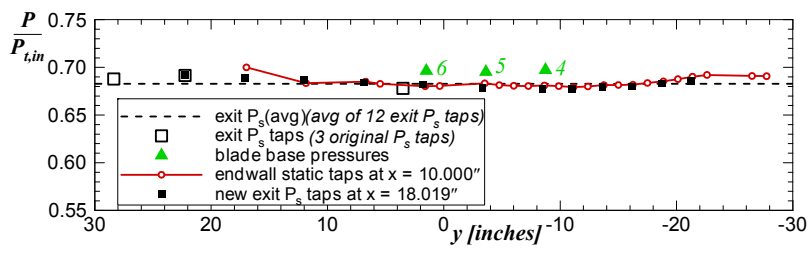

(b)

Figure 7.-Exit Pressure at $+29.1^{\circ}$ Incidence With Original Exhaust (a) and New Exhaust (b).

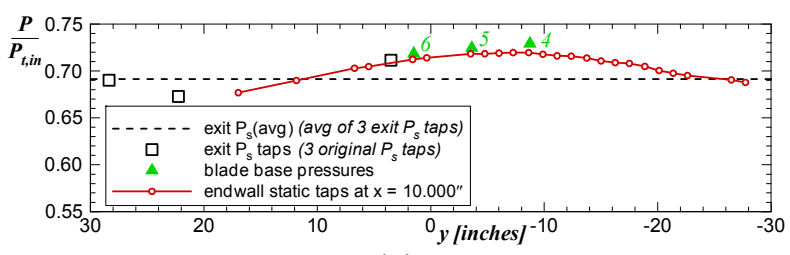

(a)

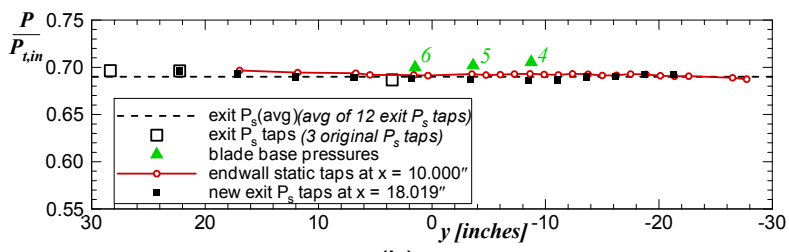

(b)

Figure 8.-Exit Pressure at $+9.1^{\circ}$ Incidence With Original Exhaust (a) and New Exhaust (b).

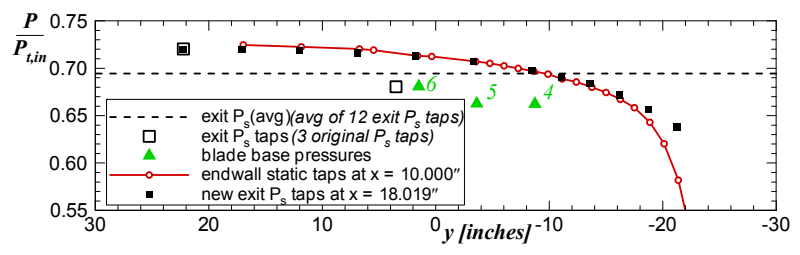

Figure 9.-Exit Pressure at $-11.4^{\circ}$ Incidence.

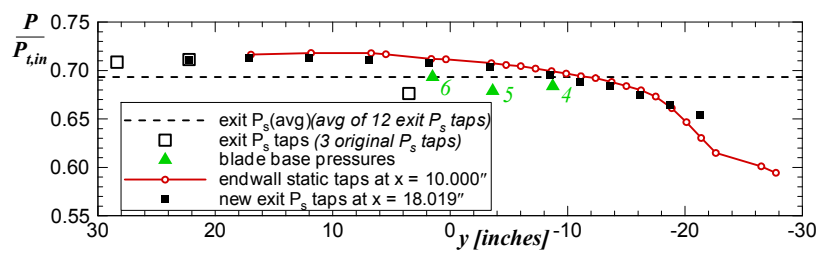

Figure 10.-Exit Pressure at $-46.5^{\circ}$ Incidence. 

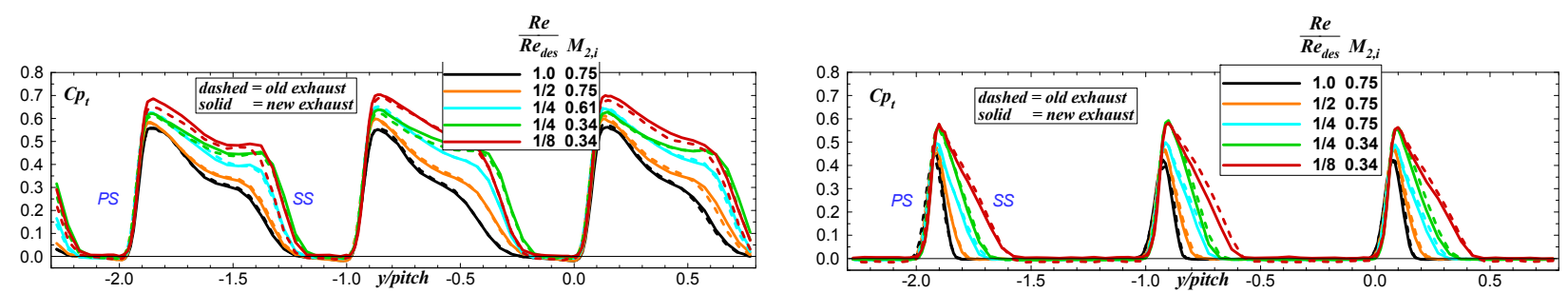

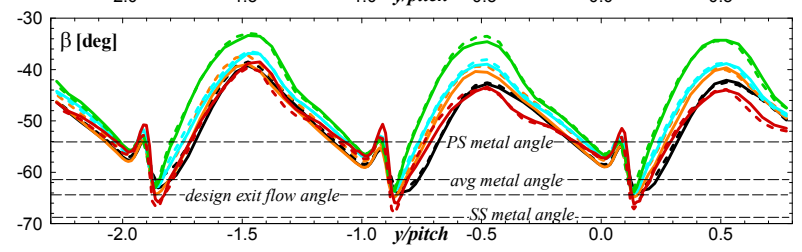

(a)

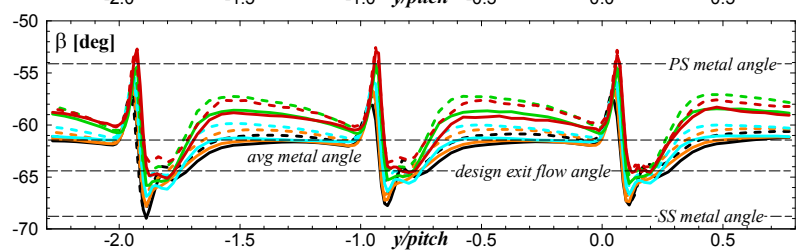

(b)

Figure 11.-Exit Total Pressure and Exit Flow Angles for (a) $+29.1^{\circ}$ and (b) $+9.1^{\circ}$ Incidence Angles.

Exit total pressure and flow angle measurements reveal that the static-pressure nonuniformity has little effect on the loss and flow angle periodicity of the three measurement passages of interest. The midspan loss coefficients and local exit flow angles are compared at $i=+29.1^{\circ}$ at five flow conditions in Figure 11(a). The new cascade data are shown as solid lines and the original data are shown as the dashed lines. Both the total pressure and flow angle data show excellent repeatability and periodicity. Figure 11(b) compares the data at the $+9.1^{\circ}$ angle. The measured total pressures are highly repeatable and the exit total pressures and flow angles are periodic. However, the new exhaust configuration did result in higher exit flow angles. A detailed discussion of the exit total pressures and flow angles is provided in the following section.

\section{Impact of Incidence Angle and Reynolds Number on Exit Surveys}

The effect of Reynolds number and Mach number variation on the local exit total pressure coefficient (top) and the flow angle (bottom) for the $+29.1^{\circ}$ incidence angle is shown in Figure 11(a). The extreme positive $29.1^{\circ}$ incidence angle constitutes the most highly loaded, highest flow-turning configuration of the test series. At this condition, the cross-passage pressure gradient establishes a strong secondary flow field, which transports low-momentum boundary-layer flow to the suction-side of the blading. Note (Appendix) that the endwall boundary-layers are a significant fraction of the $6.000 \mathrm{in}$. blade span. The aspect ratio of the test blading is sufficiently low that the low-momentum flow collects at the midspan symmetry plane on the suction-side of the blades. The aerodynamic blockage associated with the lowmomentum region is susceptible to rapid growth in the negative streamswise pressure gradient, and may ultimately separate. The combination of the strong secondary flows and the adverse pressure gradient on the highly loaded suction side leads to the nonuniformity ("wake") of shown in Figure 11(a). The wake at this extreme positive incidence angle extends over the majority of the blade pitch. The width and depth of the wake increases as the Reynolds number decreases. At the two 1/4 Reynolds number conditions, the maximum value of $C p_{t}$ in the distortion (wake) remains constant as the exit Mach number varies. The exit flow angle data show that there is a corresponding decrease in flow turning as the Reynolds number decreases, with the exception of the 1/8 Reynolds number case which has the highest flow turning. Though this last case appears anomalous, the flow angle data taken before and after the facility modifications show consistent behavior.

At the lower positive incidence angle of $+9.1^{\circ}$, the aerodynamic loading of the blade, though higher than design-intent, is reduced relative to the +29.1 setting angle. The extensive aerodynamic-blockage on the blade suction-side decreases as shown in Figure 11(b). The response to the Reynolds number and Mach number variation is similar to that at $+29.1^{\circ}$ incidence. At this angle, the wake widths remain essentially unchanged as the Reynolds number is held constant and the Mach number is varied. The depth 
of the wake (maximum $C p_{t}$ ) varies with exit Mach number, reflective of a shift in the loading diagram with change in Mach number $(P R)$. At the design Mach number the flow angles are close to the average metal angle and flow turning decreases as the Mach number is reduced .

At the $-11.4^{\circ}$ incidence-angle cases, shown in Figure 12, the aerodynamic loading has decreased further and the wake thickens only slightly on the suction side at the 1/8 Reynolds number flow condition. The depth of the wake shows a similar trend and remains constant at the lower Mach number as the Reynolds number is varied. At the 1/2 Reynolds number case, a very slight pressure-side wake thickening is noted. The flow angles also follow the same trend as the previous incidence angles; although, at this negative incidence, the flow turns to the design exit flow angle.

Results for the highest negative incidence, $i=-46.5^{\circ}$, are provided in Figure 13. The pitchwise totalpressure and flow angle distributions do not vary significantly with Reynolds or Mach number. A slight indication of possible pressure-side separation and thickening of the wake is noted.

The effects of incidence angle for the design Reynolds number $(683,000)$ and design exit Mach number (0.74) cases at the four incidence angles shown previously are summarized in Figure 14. The thick wake at the extreme positive incidence angle of $+29.1^{\circ}$ leads to high midspan loss. The midspan loss levels decrease as the inlet angle decreases. The exit flow angles increase as the incidence angles shift towards a negative incidence. Likewise, similar trends are evident in Figure 15 for the 1/8 Reynolds number at $M_{2, i}=0.35$ condition. At this lower flow condition, more effects of incidence-angle variation are occurring: both positive incidence cases reflect a degree of suction-side separation; and, there is indication of pressure-side separation at the most extreme negative incidence angle of $-46.5^{\circ}$.
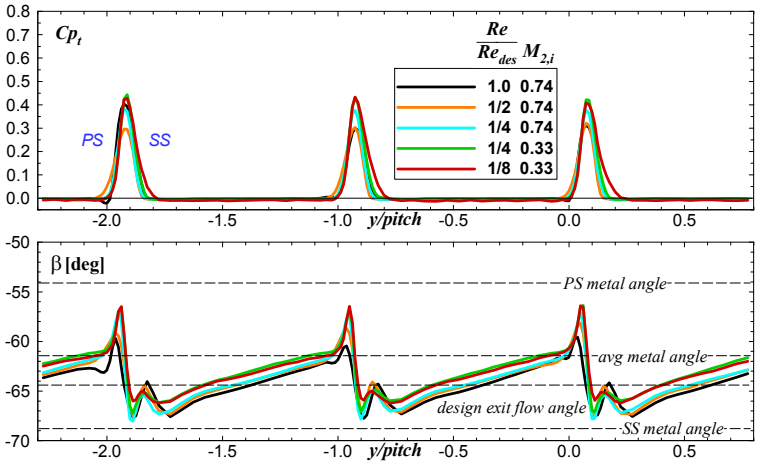

Figure 12.-Effects of Reynolds Number and Pressure Ratio at $i=-11.4^{\circ}$.
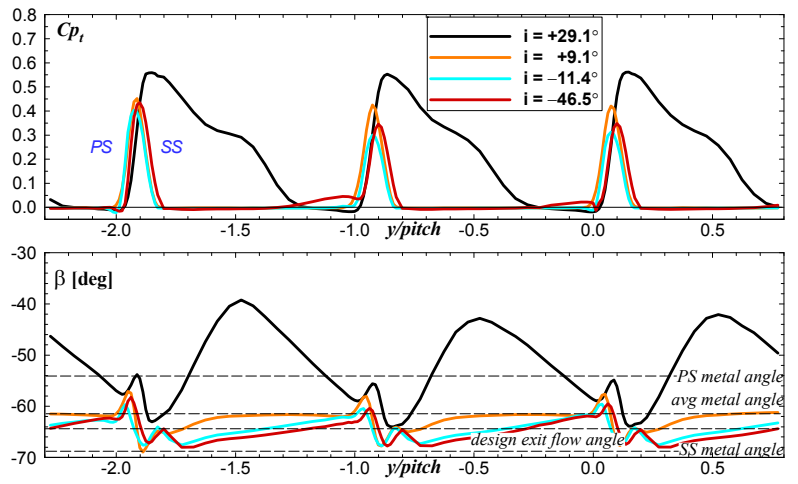

Figure 14.-Effects of Inlet Flow Angle at Design Flow Conditions $\left(R e_{C x, 1}\right.$ and $\left.M a_{i, 2}\right)$.
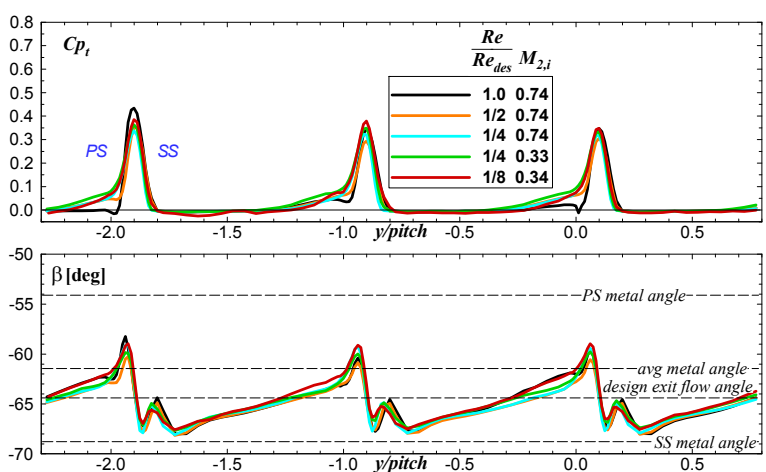

Figure 13.-Effects of Reynolds Number and Pressure Ratio at $i=-46.5^{\circ}$.
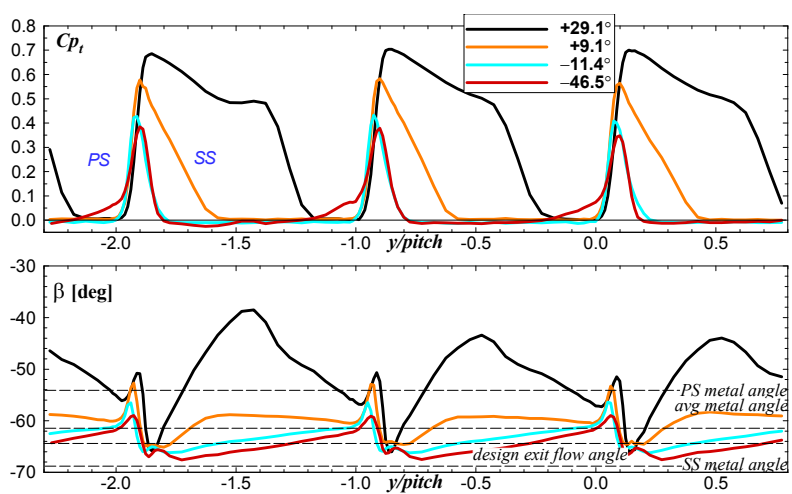

Figure 15.-Effects of Inlet Flow Angle at $\operatorname{Re}_{C x, 1}=84,500$ ( $1 / 8$ design) and $M a_{i, 2}=0.34\left(75 \% P R_{d e s}\right)$. 


\section{Impact of Incidence Angle and Reynolds Number on Blade Loading}

The blade loadings for four incidence angles, at four flow conditions are provided in Figure 16. At the $+29.1^{\circ}$ incidence angle, three-dimensional effects are evidenced by the spanwise static pressure taps on the three instrumented blades. At this angle, the weak adverse pressure gradient in the latter third of chord is consistent with growth/collection of aerodynamic blockage on the suction side as seen in the total pressure measurements of Figure 12.
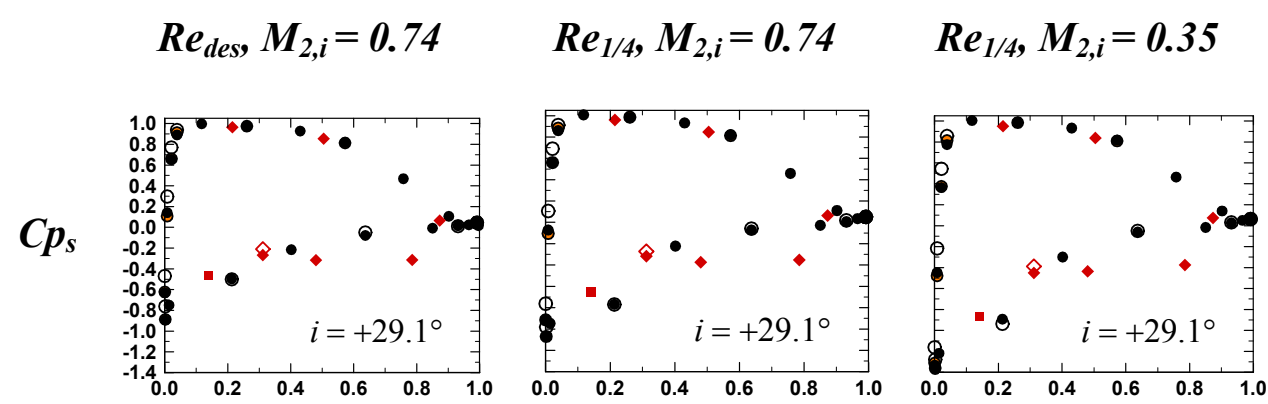

$R e_{1 / 8}, M_{2, i}=0.35$
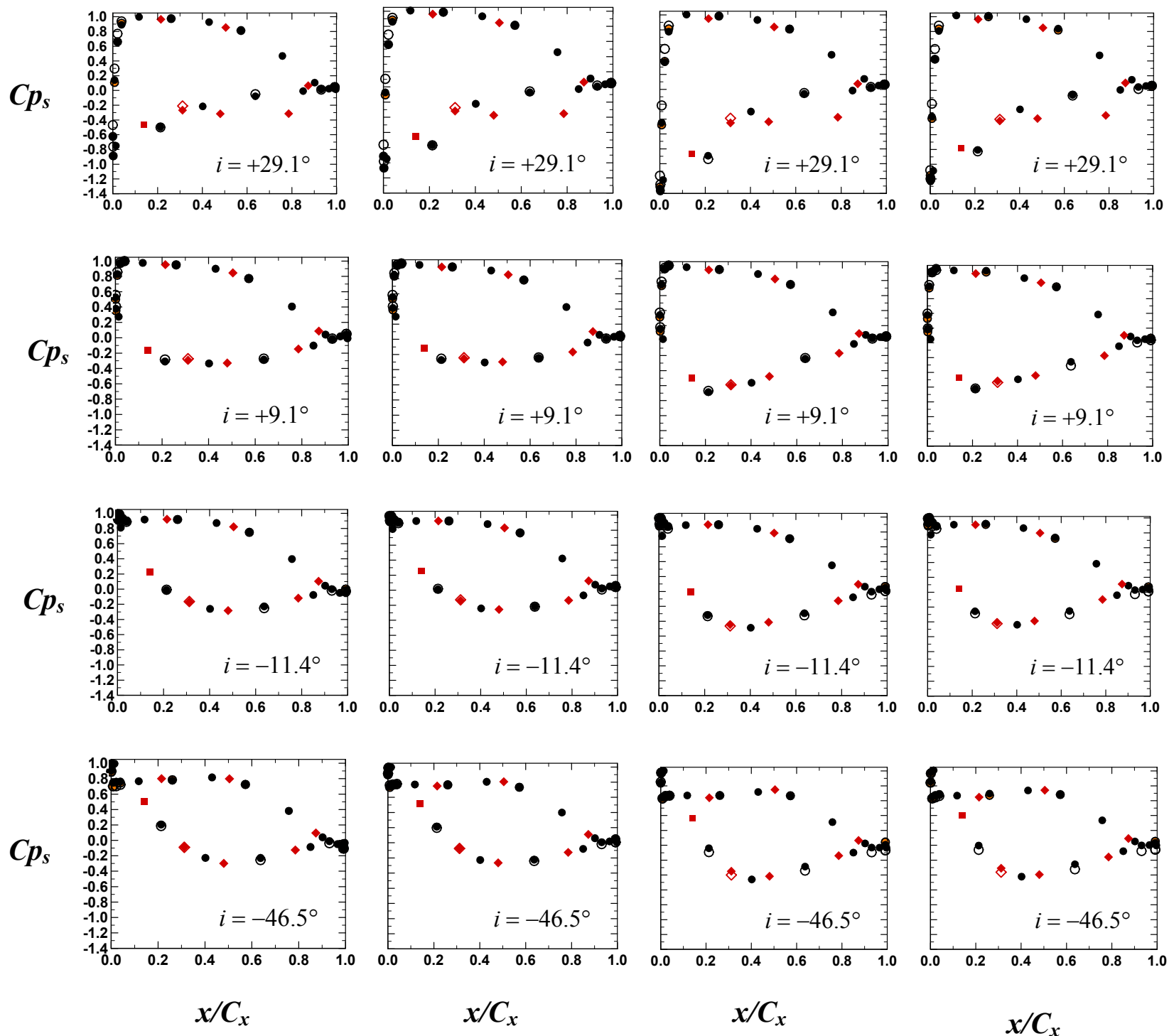

Figure 16.-Blade Loading as a Function of Incidence Angle, Mach Number, and Reynolds Number. 
Each incidence angle shows reasonable periodicity between the three instrumented blades. The blade loading increases slightly due to the Mach number variation between the two 1/4 Reynolds number cases for each angle tested. At all angles except the $+29.1^{\circ}$ case, a comparison of the $1 / 4 \operatorname{Re}$ cases shows that the location of the minimum suction surface pressure moves forward as the exit Mach number is reduced. The net aerodynamic loading and turning of the negative incidence cases is lower, particularly at $i=-46.5^{\circ}$, relative to the positive incidence angles. The large negative incidence causes the pressure surface and suction surface blade loadings to be inverted near the leading edge. The magnitude of the inversion is larger at the lower exit Mach numbers. At a fixed negative incidence, the loading diagram remains fairly constant as Reynolds number is varied at a fixed Mach number $(P R)$, but shifts noticeably as Mach number is changed at a fixed Reynolds number.

\section{Impact of Incidence Angle and Reynolds Number on Integrated Losses and Flow Exit Angles}

The loss coefficient, $\omega$, based on area-averaged total-pressures measured at the seven incidence angles and at each flow condition are provided in Figure 17. The integrations were calculated separately over two complete passages 4 and 5. As expected, losses increase at extreme negative and positive incidence, forming a "loss bucket". Loss levels increase, and the loss bucket narrows, with decreasing Reynolds number. Incidence tolerance increases with increasing Reynolds number.

The flow angles based on mass-weighted averaged velocity components are provided in Figure 18. The data reflect that the flow turning decreases with decreasing Reynolds number and with increasing aerodynamic loading (or increasingly positive incidence). The data asymptotically approach the design exit flow angle as the incidence is reduced to increasingly negative values.

Loss was correlated with aerodynamic loading and Reynolds number. The losses are expected to be proportional to the square of the aerodynamic loading - here the incompressible Zweifel coefficient is used - and with the turbulent $-1 / 5$ power law of a turbulent flow; i.e., $\omega \propto Z w^{2} \cdot R e^{-0.2}$. The correlation with data is shown in Figure 19. Data at the extreme negative incidence point, $-46.5^{\circ}$, do not correlate

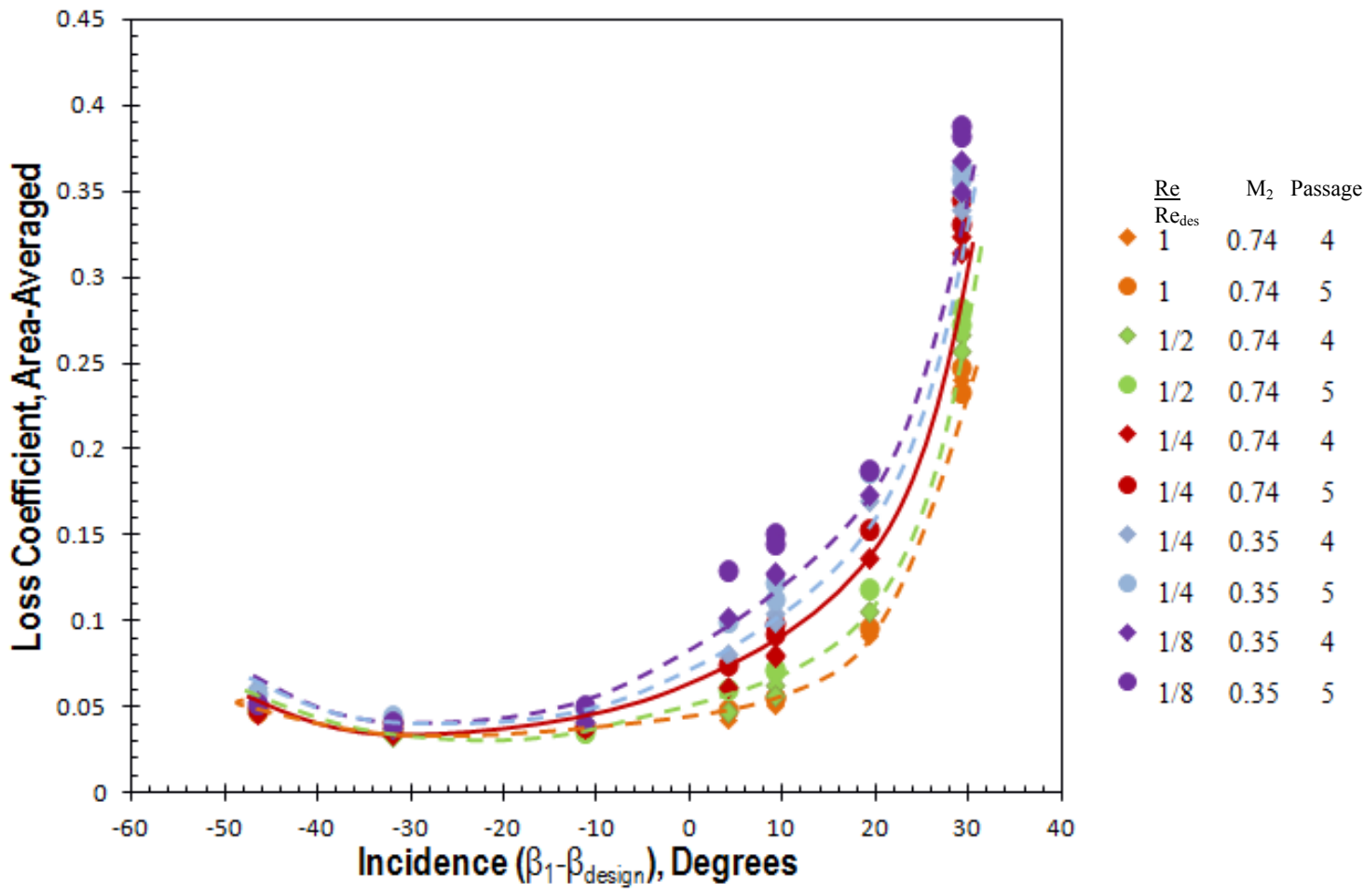

Figure 17.-Loss Coefficient as a Function of Incidence Angle and Reynolds Number. 

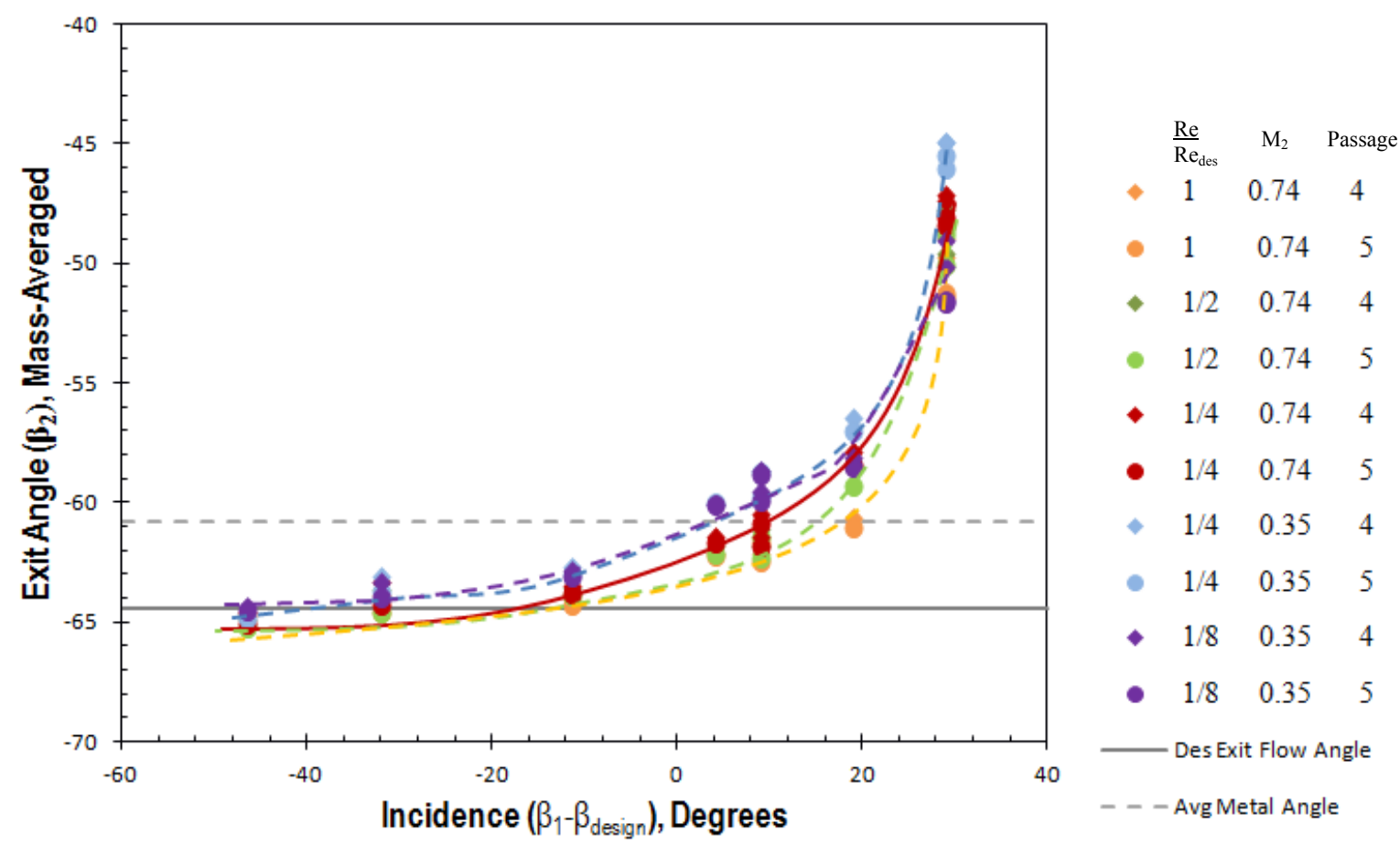

Figure 18.-Exit Flow Angle as a Function of Incidence Angle and Reynolds Number.

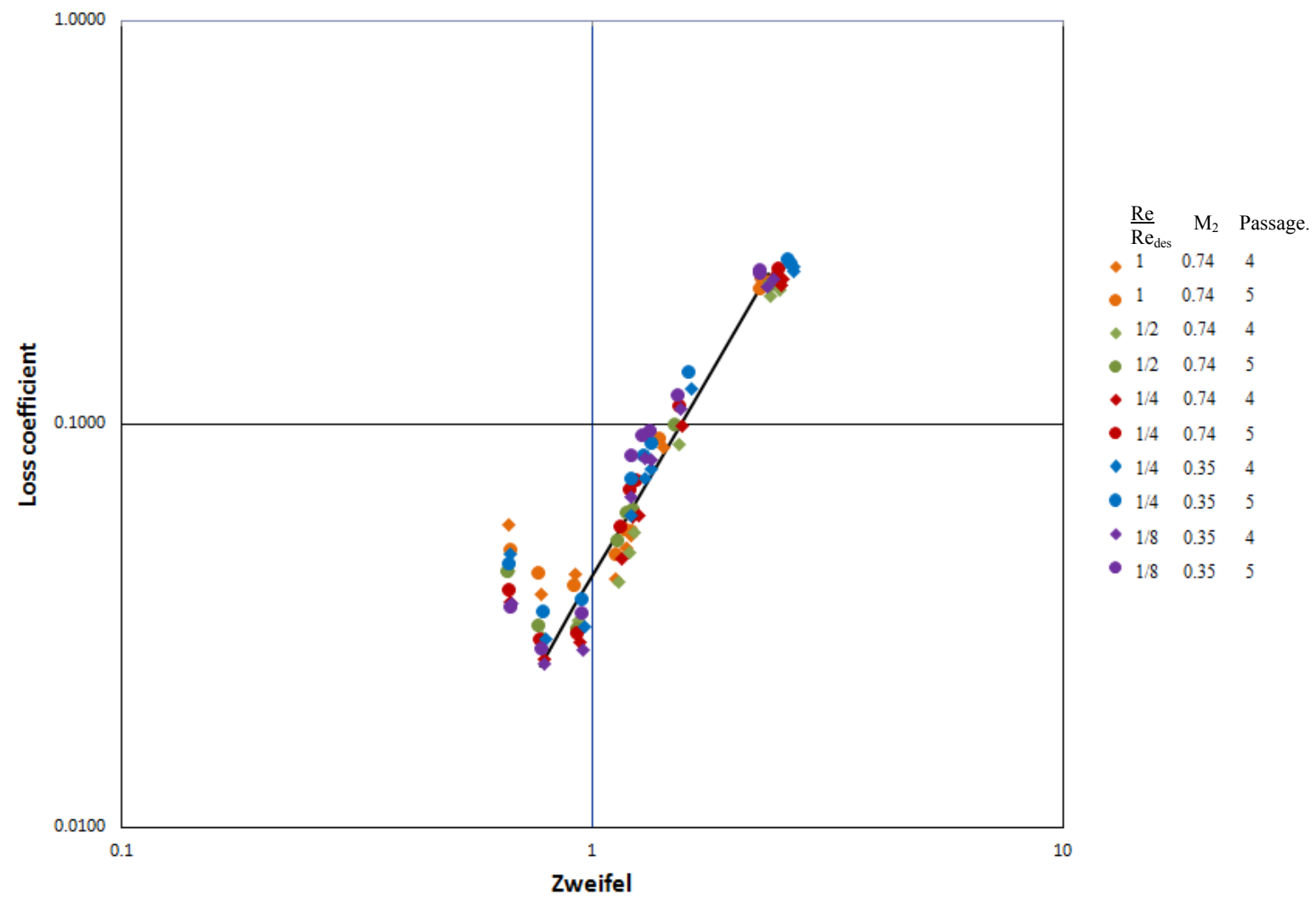

Figure 19.-Re-Scaled Loss Coefficient as a Function of Incompressible Zweifel Coefficient. 
with the traditional $Z w$ coefficient, which reflects the aerodynamic loading to effect the net turning rather than the gross blade-row turning which is related to the combined magnitudes of the negative and positive constituents of the loading diagram.

In addition to the breakdown of the adequacy of the traditional Zweifel coefficient to describe the combined (gross) aerodynamic loading of the negative and positive turning, the residual degree of scatter in Figure 19 may also be indicative of transitional flow effects in disagreement with the turbulent-flow scaling.

\section{Discussion}

The experimental results described above illustrate that the EEE tip-section blading, used in the tunnel re-baseline effort, has a wide $\left(60^{\circ}\right.$ to $\left.70^{\circ}\right)$ range of incidence over which loss levels might be deemed acceptable. The range of useful incidence is reduced as Reynolds number decreases. Particular attention in VSPT design must be paid to the impact of performance and operability lapse with decreasing Reynolds number. This is of particular concern if the turbine design is carried out with current CFD tools that inadequately capture transitional flow effects.

The loss levels and deviation angles (i.e., departure from blade exit metal angle) generally decreased with increasing negative incidence. Although the inlet air angles are well off-design at high negative incidence, the blade rows are unloaded, secondary flow fields are weak, and the flow is substantially twodimensional and follows the blading. This corroborates CFD findings at 2-D and 3-D level (Welchf (Refs. 6 and 18) and Suchezky (Ref. 19)) and recommends that particular attention be given to VSPT operating points at which aerodynamic loading is high and Reynolds numbers are low-like the LCTR $28 \mathrm{k}$-ft cruise condition (Ref. 6) - while concurrently assuring that the lower loss levels expected for high negative incidence levels (e.g., $-50^{\circ}$ ) at the higher Reynolds numbers takeoff condition are realized The VSPT will be expected to have minimal $\left(<15^{\circ}\right)$ positive incidence-angle range at low Reynolds number conditions, while being able to support large ranges of negative incidence.

No inlet turbulence grid was used in the present study. As stated, that choice was based on the intent to admit transitional flow at the higher Reynolds numbers in the tunnel relative to those of LCTR VSPT application (Ref. 7). The low freestream turbulence levels may be expected to impact loss levels at the negative and positive extremes of the loss bucket, and wherever flow separation and/or transition occurs. Further, the large inlet boundary-layer thickness (relative to blade span) and low aspect ratio of the cascade allows low-momentum flow to accumulate at midspan under conditions of high flow turning: the midspan loss levels and departure angles at the positive incidence portions of Figures 17 and 18 may be overly pessimistic, in that, reflecting the transport in the 3-D flow field, may be considerably higher than the profile losses of a 2-D section.

\section{Conclusions}

The results of the re-baseline measurements described in this paper demonstrate successful modifications of the exhaust duct and support bars in the NASA Transonic Turbine Cascade Facility to accommodate lower inlet flow angles. The facility is now better suited for the large incidence range measurements needed for the IT blade tests needed for VSPT technology development. The addition of twelve exit static pressure taps allows for increased accuracy in setting the exit Mach number and enables verification of the exit static pressure uniformity with increased accuracy.

A key finding of the study was the strong correlation of blade-row loss levels with Zweifel coefficient, along with the finding that the correlation breaks down at the extreme negative incidence. The loss levels correlated consistently with incidence angle and Reynolds number, and the loss bucket narrowed (incidence-tolerance diminished) at lower Reynolds numbers. 
The data presented in this work support the idea that particular attention must be paid to the aerodynamic loading level and Reynolds number at the more highly loaded operating points, such as LCTR VSPT cruise operation, at the cost of accepting performance at higher negative incidence operation, such as LCTR VSPT operation at takeoff, where the blade rows are unloaded and the Reynolds numbers are higher.

The detailed exit total pressures, flow angles, and blade loading data acquired over a wide range of Reynolds numbers, Mach numbers, and incidence angles show good repeatability, periodicity, and consistency with scaling laws. Those factors, along with high spatial resolution and good boundary characterization make this a valuable and challenging data set for CFD validation. 

Appendix-Test Matrix

TABLE 3.-TEST MATRIX OF INLET ANGLES

AND ACTUAL FLOW CONDITIONS

\begin{tabular}{|c|c|c|c|c|c|}
\hline$\beta_{1}$ & $\operatorname{Re}_{C x, 1}$ & $\operatorname{Re}_{C x, 2}$ & $P R$ & $M_{2, i}$ & Est. $\delta_{1}$ [in] \\
\hline \multirow{5}{*}{$\begin{array}{c}58.8^{\circ} \\
\left(i=+29.1^{\circ}\right)\end{array}$} & 685,000 & 940,700 & 1.4400 & 0.741 & 1.27 \\
\hline & 341,400 & 469,800 & 1.4383 & 0.740 & 1.40 \\
\hline & 169,800 & 232,000 & 1.2740 & 0.599 & 1.55 \\
\hline & 171,800 & 230,100 & 1.0799 & 0.333 & 1.55 \\
\hline & 90,300 & 125,700 & 1.0802 & 0.334 & 1.70 \\
\hline \multirow{5}{*}{$\begin{array}{c}48.8^{\circ} \\
\left(i=+19.1^{\circ}\right)\end{array}$} & 684,700 & $1,122,000$ & 1.4410 & 0.742 & 1.27 \\
\hline & 342,900 & 561,400 & 1.4440 & 0.744 & 1.40 \\
\hline & 170,000 & 274,700 & 1.3596 & 0.677 & 1.55 \\
\hline & 171,800 & 266,100 & 1.0806 & 0.335 & 1.55 \\
\hline & 86,300 & 136,200 & 1.0811 & 0.336 & 1.71 \\
\hline \multirow{5}{*}{$\begin{array}{c}38.8^{\circ} \\
\left(i=+9.1^{\circ}\right)\end{array}$} & 685,300 & $1,251,000$ & 1.4472 & 0.746 & 1.27 \\
\hline & 343,600 & 628,500 & 1.4427 & 0.743 & 1.40 \\
\hline & 168,200 & 307,300 & 1.4169 & 0.724 & 1.55 \\
\hline & 173,000 & 296,800 & 1.0813 & 0.336 & 1.55 \\
\hline & 84,500 & 149,000 & 1.0790 & 0.331 & 1.71 \\
\hline \multirow{5}{*}{$\begin{array}{c}33.8^{\circ} \\
\left(\mathrm{i}=+4.1^{\circ}\right)\end{array}$} & 685,100 & $1,297,000$ & 1.4405 & 0.741 & 1.27 \\
\hline & 342,300 & 653,300 & 1.4449 & 0.745 & 1.40 \\
\hline & 169,900 & 323,600 & 1.4164 & 0.723 & 1.55 \\
\hline & 170,500 & 302,300 & 1.0813 & 0.336 & 1.55 \\
\hline & 87,700 & 158,200 & 1.0803 & 0.334 & 1.70 \\
\hline \multirow{5}{*}{$\begin{array}{c}18.3^{\circ} \\
\left(i=-11.4 \cdot 1^{\circ}\right)\end{array}$} & 685,100 & $1,570,000$ & 1.4438 & 0.744 & 1.27 \\
\hline & 343,300 & 783,300 & 1.4437 & 0.744 & 1.40 \\
\hline & 170,400 & 387,700 & 1.4406 & 0.741 & 1.55 \\
\hline & 171,300 & 364,400 & 1.0805 & 0.334 & 1.55 \\
\hline & 84,630 & 183,800 & 1.0804 & 0.334 & 1.71 \\
\hline \multirow{5}{*}{$\left(i=\begin{array}{l}-2.4^{\circ} \\
\left.-32.1^{\circ}\right)\end{array}\right.$} & 684,800 & $1,649,000$ & 1.4408 & 0.742 & 1.27 \\
\hline & 343,100 & 827,700 & 1.4443 & 0.744 & 1.40 \\
\hline & 170,900 & 410,000 & 1.4407 & 0.742 & 1.55 \\
\hline & 178,200 & 387,600 & 1.0812 & 0.336 & 1.54 \\
\hline & 84,750 & 193,800 & 1.0795 & 0.332 & 1.71 \\
\hline \multirow{5}{*}{$\begin{array}{c}-16.8^{\circ} \\
\left(i=-46.5^{\circ}\right)\end{array}$} & 685,800 & $1,690,000$ & 1.4401 & 0.741 & 1.27 \\
\hline & 343,500 & 841,000 & 1.4390 & 0.740 & 1.40 \\
\hline & 171,700 & 418,600 & 1.4420 & 0.742 & 1.55 \\
\hline & 172,000 & 385,900 & 1.0800 & 0.333 & 1.55 \\
\hline & 84,760 & 192,000 & 1.0806 & 0.335 & 1.71 \\
\hline
\end{tabular}




\section{References}

1. Johnson, W., Yamauchi, G.K., and Watts, M.E., "NASA Heavy Lift Rotorcraft Systems Investigation," NASA/TP-2005-213467, Sep., 2005.

2. Acree, C.W., Hyeonsoo, Y., and Sinsay, J.D., "Performance Optimization of the NASA Large Civil Tiltrotor," Proc. of the Int. Powered Lift Conf., Jul, 2008.

3. Wilkerson, J.B. and Smith, R.L., "Aircraft System Analysis of Technology Benefits to Civil Transport Rotorcraft," NASA/CR-2009-214594, Jun., 2009.

4. Stevens, M.A., Handschuh, R.F., Lewicki, D.G., "Variable/Multispeed Rotorcraft Drive System Concepts," NASA/TM-2009-215456; also ARL-TR-4728, Mar., 2009.

5. D'Angelo, M., "Wide Speed Range Turboshaft Study,” NASA/CR—1995-198380, Aug., 1995.

6. Welch, G.E., "Assessment of Aerodynamic Challenges of a Variable-Speed Power Turbine for a Large Civil Tilt-Rotor Application," Proc. of the AHS Int. $66^{\text {th }}$ Annual Forum, Arizona, May 2010; also NASA/TM-2010-216758.

7. Welch, G.E., McVetta, A.B., Stevens, M.A., Howard, S.A., Giel, P.W., Ameri, A.A., Waiming, T., Skoch, G.J., Thurman, D.R., "Variable-Speed Power-Turbine Research at Glenn Research Center," Proc. of the AHS Int.68 ${ }^{\text {th }}$ Annual Forum, Texas, May 2012; also NASA/TM-2012-217605.

8. Stabe, R.G. and Kline, J.F., "Incidence Loss for a Core Turbine Rotor Blade in a Two-Dimensional Cascade,” NASA TM-X-3047, 1974.

9. Kline, J.F., Moffit, T.P., Stabe, R.G., "Incidence Loss for Fan Turbine Rotor Blade in TwoDimensional Cascade," NASA TP-2188, 1983.

10. Ford, A., Bloxham, M., Turner, E., Clemens, E., Gegg, S., "Design Optimization of IncidenceTolerant Blading Relevant to Large Civil Tilt-Rotor Power Turbine Applications," NASA/CR2011-217016, 2012.

11. Timko, L. P., "Energy Efficient Engine High Pressure Turbine Component Test Performance Report," NASA/CR-1984-168289, 1984.

12. Ameri, A.A., "Implementation of a Transition Model in a NASA Code and Validation Using Heat Transfer Data on a Turbine Blade," NASA/CR_-2012-217436, April 2012.

13. Giel, Paul W., Robert J. Boyle, and Ronald S. Bunker "Measurements and Predictions of Heat Transfer on Rotor Blades in a Transonic Turbine Cascade," ASME J. of Turbomachinery, Vol. 126, No. 1, pp. 110-121, Jan. 2004.

14. Giel, P.W., Thurman, D.R., Lopez, I., Boyle, R.J., Van Fossen, G.J., Jett T.A., Camperchioli, W.P., La, H., "Three Dimensional Flow Field Measurements in a Transonic Turbine Cascade," ASME 96-GT-113, presented at the 1996 ASME/IGTI Gas Turbine Conference, Birmingham, U.K., June 10-13, 1996. Also NASA/TM-107388 and U.S. Army ARL-TR-1252.

15. Verhoff, V.G., Camperchioli, W.P, and Lopez, I., 1992,'Transonic Turbine Blade Cascade Testing Facility," AIAA Paper No. 92-4034, NASA TM-105646.

16. Giel, P.W., Sirbaugh, J.R, Lopez, I., and Van Fossen, G.J., 1996b, ”Three Dimensional Navier Stokes Analysis and Redesign of an Imbedded Bellmouth Nozzle in a Turbine Cascade Inlet Section," ASME Journal of Turbomachinery, Vol 118, No 3, pp. 529-535. NASA/TM-107284 and U.S. Army ARL-MR-152.

17. Yavuzkurt, S., 1984, "A Guide to Uncertainty Analysis of Hot-Wire Data," Journal of Fluids Engineering, Vol. 106, pp. 181-186.

18. Welch, G.E., "Computational Assessment of the Aerodynamic Performance of a Variable-Speed Power Turbine for Large Civil Tilt-Rotor Application," Proc. of the AHS Int. $67^{\text {th }}$ Annual Forum, May, 2011; also NASA/TM-2011-217124, Nov., 2011.

19. Suchezky, M., "Variable-speed power turbine for the Large Civil Tilt Rotor," NASA/CR - 2012217424, Feb. 2012. 



\begin{tabular}{|c|c|c|}
\hline \multicolumn{2}{|c|}{ REPORT DOCUMENTATION PAGE } & $\begin{array}{l}\text { Form Approved } \\
\text { OMB No. 0704-0188 }\end{array}$ \\
\hline \multicolumn{3}{|c|}{ 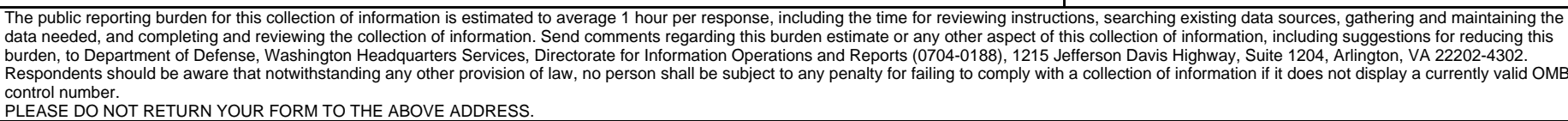 } \\
\hline $\begin{array}{l}\text { 1. REPORT DATE (DD-MM-YYYY) } \\
01-08-2013\end{array}$ & $\begin{array}{l}\text { 2. REPORT TYPE } \\
\text { Technical Memorandum }\end{array}$ & 3. DATES COVERED (From - To) \\
\hline \multirow{3}{*}{\multicolumn{2}{|c|}{$\begin{array}{l}\text { 4. TITLE AND SUBTITLE } \\
\text { Aerodynamic Investigation of Incidence Angle Effects in a Large Scale Transonic Turbine } \\
\text { Cascade }\end{array}$}} & 5a. CONTRACT NUMBER \\
\hline & & 5b. GRANT NUMBER \\
\hline & & 5c. PROGRAM ELEMENT NUMBER \\
\hline \multirow{3}{*}{\multicolumn{2}{|c|}{$\begin{array}{l}\text { 6. AUTHOR(S) } \\
\text { McVetta, Ashlie, B.; Giel, Paul, W.; Welch, Gerard, E. }\end{array}$}} & 5d. PROJECT NUMBER \\
\hline & & 5e. TASK NUMBER \\
\hline & & $\begin{array}{l}\text { 5f. WORK UNIT NUMBER } \\
\text { WBS 380046.02.03.02.01.01 }\end{array}$ \\
\hline \multicolumn{2}{|c|}{$\begin{array}{l}\text { 7. PERFORMING ORGANIZATION NAME(S) AND ADDRESS(ES) } \\
\text { National Aeronautics and Space Administration } \\
\text { John H. Glenn Research Center at Lewis Field } \\
\text { Cleveland, Ohio 44135-3191 }\end{array}$} & $\begin{array}{l}\text { 8. PERFORMING ORGANIZATION } \\
\text { REPORT NUMBER } \\
\text { E-18746 }\end{array}$ \\
\hline \multirow{2}{*}{\multicolumn{2}{|c|}{$\begin{array}{l}\text { 9. SPONSORING/MONITORING AGENCY NAME(S) AND ADDRESS(ES) } \\
\text { National Aeronautics and Space Administration } \\
\text { Washington, DC 20546-0001 }\end{array}$}} & $\begin{array}{l}\text { 10. SPONSORING/MONITOR'S } \\
\text { ACRONYM(S) } \\
\text { NASA }\end{array}$ \\
\hline & & $\begin{array}{l}\text { 11. SPONSORING/MONITORING } \\
\text { REPORT NUMBER } \\
\text { NASA/TM-2013-218070 }\end{array}$ \\
\hline \multicolumn{3}{|c|}{$\begin{array}{l}\text { 12. DISTRIBUTIONIAVAILABILITY STATEMENT } \\
\text { Unclassified-Unlimited } \\
\text { Subject Category: } 2 \\
\text { Available electronically at http://www.sti.nasa.gov } \\
\text { This publication is available from the NASA Center for AeroSpace Information, 443-757-5802 }\end{array}$} \\
\hline
\end{tabular}

\section{SUPPLEMENTARY NOTES}

\section{ABSTRACT}

Aerodynamic measurements showing the effects of large incidence angle variations on an HPT turbine blade set are presented.

Measurements were made in NASA's Transonic Turbine Blade Cascade Facility which has been used in previous studies to acquire detailed aerodynamic and heat transfer measurements for CFD code validation. The current study supports the development of variable-speed power turbine (VSPT) speed-change technology for the NASA Large Civil Tilt Rotor (LCTR) vehicle. In order to maintain acceptable main rotor propulsive efficiency, the VSPT operates over a nearly 50 percent speed range from takeoff to altitude cruise. This results in $50^{\circ}$ or more variations in VSPT blade incidence angles. The cascade facility has the ability to operate over a wide range of Reynolds numbers and Mach numbers, but had to be modified in order to accommodate the negative incidence angle variation required by the LCTR VSPT operation. Using existing blade geometry with previously acquired aerodynamic data, the tunnel was re-baselined and the new incidence angle range was exercised. Midspan exit total pressure and flow angle measurements were obtained at seven inlet flow angles. For each inlet angle, data were obtained at five flow conditions with inlet Reynolds numbers varying from $6.83 \times 10^{5}$ to $0.85 \times 10^{5}$ and two isentropic exit Mach numbers of 0.74 and 0.34 . The midspan flowfield measurements were acquired using a three-hole pneumatic probe located in a survey plane 8.6 percent axial chord downstream of the blade trailing edge plane and covering three blade passages. Blade and endwall static pressure distributions were also acquired for each flow condition.

\section{SUBJECT TERMS}

Turbomachinery; Turbines; Axial flow turbines; Aerodynamics

\begin{tabular}{|c|c|c|c|c|c|}
\hline \multicolumn{3}{|c|}{ 16. SECURITY CLASSIFICATION OF: } & \multirow{2}{*}{$\begin{array}{l}\text { 17. LIMITATION OF } \\
\text { ABSTRACT } \\
\text { UU }\end{array}$} & \multirow{2}{*}{$\begin{array}{l}\text { 18. NUMBER } \\
\text { OF } \\
\text { PAGES } \\
26\end{array}$} & \multirow{2}{*}{$\begin{array}{l}\text { 19a. NAME OF RESPONSIBLE PERSON } \\
\text { STI Help Desk (email:help@sti.nasa.gov) } \\
\text { 19b. TELEPHONE NUMBER (include area code) } \\
\text { 443-757-5802 }\end{array}$} \\
\hline $\begin{array}{l}\text { a. REPORT } \\
\mathrm{U}\end{array}$ & $\begin{array}{l}\text { b. ABSTRACT } \\
U\end{array}$ & $\begin{array}{l}\text { c. THIS } \\
\text { PAGE } \\
\text { U }\end{array}$ & & & \\
\hline
\end{tabular}



